\title{
Integrated Pest Management of Cotton Thrips, Thrips tabaci (Lindeman, 1889) through Selected Pesticides under Vitro Conditions
}

\author{
Zafar Hussain Shah ${ }^{1}$, Hakim Ali Sahito ${ }^{1 *}$, Tasneem Kousar ${ }^{1}$, Muhammad Mithal Rind ${ }^{1}$, \\ Faheem Ahmed Jatoi ${ }^{1}$ and Wali Muhammad Mangrio ${ }^{1}$ \\ ${ }^{I}$ Department of Zoology, Faculty of Natural Sciences, Shah Abdul Latif University, Khairpur Mir's, Sindh - \\ Pakistan
}

*Corresponding Author: Hakim Ali Sahito, Department of Zoology, Faculty of Natural Sciences, Shah Abdul Latif University, Khairpur Mir's, Sindh - Pakistan

\begin{abstract}
The cotton crop is known as major crop of Pakistan, vigorously damaged by many insect pests, among them, the research study was conducted on most vital early-season sucking insect pest, thrips (T. tabaci) under cotton field conditions at district: Khairpur during, 2015. The six treatments and replicated four times based on five application of different pesticides of different groups such as; $T_{1}=$ Pyriproxyfen, $T_{2}=$ Acetamaprid, $T_{3}=$ Acephate, $T_{4}=$ Diafenthiuron and $T_{5}=$ Nitenpyram and $T_{6}=$ control plot (without use of pesticide). The results showed that, Acephate pesticide was found more effective and Pyriproxyfen with least effective. Acephate showed the overall reduction (37.39\%) in overall sprays when compared with the control (un-sprayed) plot. The second pesticide Acetamaprid was observed with the overall reduction (23.68 $\pm 7.68 \%)$ followed by Nitenpyram (19.45 $\pm 9.57 \%)$, Diafenthiuron $(19.33 \pm 4.13 \%)$ and Pyriproxyfen $(1.30 \pm 16.94 \%)$ when compared with control plot (11.50 \pm 1.35$)$, respectively. The analysis of variance showed the significant difference among all pesticides ( $p<0.05$ ). It is concluded that only Acephate gave the better results up to $12^{\text {th }}$ day among all pesticides therefore, it is suggested to be applied for controlling of T. tabaci on the cotton crop under field conditions.
\end{abstract}

Keywords: Thrips, Insecticides, G. hirsutum, field conditions.

\section{INTRODUCTION}

Cotton, Gossypium hirsutum (L.) is known as "white gold" belongs to the family Malvaceae, it is the main fiber and cash crop of Pakistan (Sahito et al., 2015) that grows in both tropical and sub-tropical regions throughout the world about 111 countries (Ozyigit et al., 2007) with multiple products, animal nutrition and manufacturing companies (Shah et al., 2016). Pakistan ranks $5^{\text {th }}$ in the world and in the largest exporting countries of raw cotton on $3^{\text {rd }}$ and $4^{\text {th }}$ in cotton consuming countries, about $10 \%$ contribution in GDP and 55\% on the country's foreign exchange is only due to cotton and cotton products. Overall $30 \%-40 \%$ of cotton ends up as domestic consumption of finished products. The remaining is exported as raw cotton, yarn, fabrics and garments (PAR, 2016). It maintains a million people to earn on farms and factories ginning, weaving and cooking oil industries soap factories, therefore, called for the right of the economy a lifeline in many Asian countries (Ahmad, 1999). This crop is infested by various kinds of insect pests in different stages of growth, as compared to other crops (Uthamasamy, 1994), during growth period of this crop, 148 insect pests have been recorded on this crop, out of which 17 species recorded as major insect pests (Abbas, 2001). Same wise; Thrips, Thrips tabaci (Lindeman); Jassids, Amrasca biguttula biguttula (Ishida); Whitefly, Bemisia tabaci (Gennadius); Aphids, Aphis gossypii (Glover) and mealybug, Phenacoccus solenopsis (Tinsley) (Sahito et al., 2011) attacked on cotton crop. Among them cotton thrips have accomplished the status of a usual cotton insect pest in the Punjab region of Pakistan (Ali et al., 1993). T. tabaci is the most vital early-season sucking insect pest on cotton (Wilson and Bauer, 1993). The maximum population of cotton thrips was recorded in the second fortnight of September (Gupta et al., 1997). Thrips harmed seedlings occasionally show explosion of monopodial branches (Gaines, 1934). 
The various factors such as; cultural, mechanical, physical, biological and chemical components of integrated pest management are used to control this insect pest. Among them, the chemical control is the most popular weapon because it gives faster results. For the management of thrips has been tested a number of pesticides of different groups and are considered in the framework of the general recommendation. However, the cotton crop is more vulnerable to pests herbivore subjected to highly usage of pesticides which have also negative effect on parasitic and predatory fauna but it is the only way to control the infection on a large scale and spread of a sudden pest (Afzal, 1969). In Pakistan, imported pesticides worth more than 10 billion rupees, of which about $70 \%-80 \%$ are sprayed against cotton pests (Anonymous, 2008). Pesticides were used for the first time in 1950 in Pakistan to combat the locust attack. In 1954, the value of imports of chemical pesticides to 254 tons in 1980 used approximately $90 \%$ of the pesticides on the cotton crop, more than 6620000 acres used to grow cotton crops any target pesticide use (Khan et al., 2002) that $83 \%$ of the pesticides were used to control insect pests in cotton fields. Conventional pesticides are the only option for a quick knockout blow of insects, but the wise usage remains a problem. Such as; the development of resistance and an increase in the cost of production, pollution and so different researchers test different spraying to control the cotton thrips, and get different results. Neonicotinoids are available in commercial products Imidacloprid, Acetamiprid, Thiacloprid and Thiamethoxam. These pesticides are important for agriculture because of their activity against sucking pests (Iwasa et al., 2004; Anikwe et al., 2009; Zhang et al., 2011; Carvalho et al., 2010). It's an urgent need to use the new chemical pesticides, which are not only control insect pests goal, but also safer for beneficial insects such as ladybird beetle, spider, Chrysoperlla spp., Trichogramma spp., and the human being as well. Pesticides neonicotinoid (Imidacloprid) interfere with nicotine acetylcholine receptors in the nervous system of insects (Yamamoto, 1996). Previous investigations have been conducted on the effectiveness of different pesticides to control the absorption of insect pests by different operators (Ahmed and Hussein, 1993; parasite et al., 1995; Attaque and Ghaffar, 1996; Wahla et al, 1997; Natwick, 1999; Saleem et al., 2001; Aslam et al., 2004; Khattak et al., 2006; Shah et al., 2007). The main objective of the present study is to compare the toxicity of selected pesticides against thrips, T. tabaci on cotton crop and to recommend the most effective pesticide against this insect pest under field conditions.

\section{Materials AND MethodS}

The field study was conducted at Lakyari Agricultural Farm at Saidi lower near Kamaldero, Taluka: Gambat, District: Khairpur - Sindh during Kharif Season, 2015 to compare the toxicity of five selected pesticides. The pesticides with their toxicity used for cotton thrips under vitro conditions $T_{1}=$ Pyriproxyfen (Admril)10.8 EC with compound Insect Growth Regulator (IGR), $400 \mathrm{ml}$ dose /acre, FMC (Pvt.) Ltd at $50 \mathrm{ml} /$ tank. $\mathrm{T}_{2}=$ Acetamaprid (Mospilan) $20 \mathrm{SP}$ with compound Neonicotinoid $200 \mathrm{~g}$, Arysta (Pvt.) Ltd. $25 \mathrm{~g} /$ tank. $\mathrm{T}_{3}=$ Acephate 75 SP (Safate) with compound Organophosphate 300 g, R.B Avari Enterprises (Pvt.) Ltd. 37 g / tank. $\mathrm{T}_{4}=$ Diafenthiuron (Polo) $500 \mathrm{SC}$ with compound Thiourea $200 \mathrm{ml}$, Syngenta (Pvt.) Ltd. $25 \mathrm{ml} /$ tank. $\mathrm{T}_{5}=$ Nitenpyram $10 \mathrm{SL}$ (Amrasca) with compound Neonicotinoid $200 \mathrm{ml}$, Agri Farm Services (Pvt.) Ltd. $25 \mathrm{ml} /$ tank. $\mathrm{T}_{6}=$ Control plot (without use of pesticides).

The pesticides used in the experiment were obtained from the local market. The cotton seeds ( $c v . B t$., 114) were sown on ridges in the direction from north to south in a Randomize Complete Block Design (RCBD) having a treatment size of $(29 \times 29 \mathrm{~m})$ of each. There were 5 treatments and replicated 4 times as mentioned above whereas; the control plot was kept without using any pesticide. The plots were separated from each other by keeping a space of 2 feet between treatments and replications. The distance between ridge to ridge 18 and plant to plant was 9 to 12 inches, respectively. All agronomical practices such as thinning and weeding were done manually. Before sowing the cotton crop, the weedicide was applied to control the un-wanted plants. The sprayer person was covered with mask on face, hand gloves in hands and clothes covered on whole body.

When the sucking insect pest made their initial appearance sporadically, one month after germination, the thrips population was reached at economic thresh hold level (ETL) i.e., more than ten adults or nymphs of thrips/leaf then pesticides were sprayed with shoulder mounted knapsack sprayer at that time to reduce the pest population. All the pesticides were applied at the field recommended rate / dose. The population fluctuation observed naturally occurrence under control plot with the management of beneficial insects. The data was taken atpre-treatment and post-treatment as; before 
Integrated Pest Management of Cotton Thrips, Thrips tabaci (Lindeman, 1889) through Selected Pesticides under Vitro Conditions

and after the spray, thus the data was collected at $24,48,72$ hours, $7^{\text {th }}$ day and $12^{\text {th }}$ day post spraying. Alive sucking insect pest was counted at randomly on 3 leaves 1 from top, 1 from middle and 1 from bottom side of the plant from 20 plants.

Thus; the data collected was subjected to analysis of variance and mean values compared with LSD test using analytical statistics package 8.1 software (USA) whereas; the reduction percentage of pesticides was observed by using Henderson and Tilton, 1955 formula: Reduction $\%=(1-\mathrm{Ta} \times \mathrm{Cb} /$ $\mathrm{Ca} \times \mathrm{Tb}) \times 100$.

\section{Where:}

$$
\begin{aligned}
& \boldsymbol{T} \boldsymbol{a}=\text { Infestion in the treated plot after treatment. } \\
& \boldsymbol{T} \boldsymbol{b}=\text { Infestation in the treated plot before treatment. } \\
& \boldsymbol{C} \boldsymbol{a}=\text { Infestation in the control plot after treatment. } \\
& \boldsymbol{C b}=\text { Infestation in the control plot before treatment. }
\end{aligned}
$$

\section{RESUlts}

The effectiveness of pesticides was assessed against thrips, Thrip tabaci (Lind.) (Thysanoptera: Thripidae) under cotton crop vitro conditions cultivated at district: Khairpur - Sindh. Because of extreme hot conditioning atmosphere, this locality is outstanding for the cultivation of cotton crop and the date palm all over the country. So, the research work was conducted on this significant cotton crop which was managed through the diverse pesticides as the thrips are the tiny, cylinder pests with fringed wings and exclusive asymmetrical mouthparts. During research study, it was noticed that the thrips are most affective agent to the cotton crop from beginning stage up to collecting. In this manner, it was important to deal with the pest accordingly with the assistance of various insecticidal dosages.

\section{First spray:}

The results of the first spray showed that the overall mean population of thrips was observed (15.00) in pre - treatment data collection when sprayed with Acephate pesticide, the post-treatment data showed that the $(85.12 \%)$ was reduced after one day / 24 hours spray. Thus, the second day on 48 hours was observed (30.33\%), on third day after 72 hours (49.08\%), on seventh day (84.20\%) and on twelfth day $(55.82 \%)$ reduced which showed the overall reduction $(60.91 \pm 10.56 \%)$ in first spray when compared with the control (un-sprayed) plot. The second pesticide Diafenthiuron was observed with the overall reduction $(9.18 \pm 25.08 \%)$ followed by Acetamaprid (-4.16 $\pm 26.79 \%)$, Nitenpyram ($18.00 \pm 36.53 \%)$ and Pyriproxyfen $(-64.97 \pm 53.96 \%)$ when compared with control plot $(21.56 \pm 5.78)$ with overall mean population (Table-1), respectively. The analysis of variance showed the significant difference among all pesticides $(\mathrm{DF}=5,24 ; \mathrm{F}=1.84 ; \mathrm{P}=0.1421)$ used to control the thrips at $(\mathrm{P}<0.05)$. Among these pesticides only Acephate pesticide provided the better results up to $12^{\text {th }}$ day against thrips. After application of this pesticide it was observed the lesser population of thrips upto second spray, latter on the population went beyond the economic threshold level (ETL) after $12^{\text {th }}$ day. When the higher population was observed after $15^{\text {th }}$ day the second spray was applied for better management of thrips in cotton crop.

Table- 1. Overall mean and reduction \% at pre and post treatments of different pesticides against Thrips $\left(1^{\text {st }}\right.$ spray) under cotton field conditions

\begin{tabular}{|l|l|l|l|l|l|l|l|}
\hline \multirow{3}{*}{ Pesticides } & \multirow{2}{*}{$\begin{array}{l}\text { Pre- } \\
\text { treatment }\end{array}$} & $24 \mathrm{~h}$ & $48 \mathrm{~h}$ & $72 \mathrm{~h}$ & $7^{\text {th }}$ day & $12^{\text {th }}$ day & Mean and Reduction $\% \pm$ SE \\
\hline \multirow{2}{*}{ Acephate } & 15.00 & 1.56 & 2.53 & 2.80 & 2.60 & 2.86 & $2.47 \pm 0.24$ \\
\cline { 2 - 8 } & Reduction $\%$ & 85.12 & 30.33 & 49.08 & 84.20 & 55.82 & $60.91 \pm 10.56^{\mathrm{a}}$ \\
\hline \multirow{2}{*}{ Diafenthiuron } & 15.90 & 3.70 & 1.33 & 9.26 & 17.30 & 8.80 & $8.08 \pm 2.75$ \\
\cline { 2 - 8 } & Reduction \% & 66.71 & 65.45 & -58.87 & 0.85 & -28.24 & $9.18 \pm 25.08^{\text {ab }}$ \\
\hline \multirow{2}{*}{ Pyriproxyfen } & 21.20 & 13.03 & 14.60 & 23.53 & 8.73 & 10.26 & $14.03 \pm 2.59$ \\
\cline { 2 - 8 } & & - & - & & & \\
& Reduction \% & 12.06 & 184.45 & 202.77 & 62.47 & -12.14 & $-64.97 \pm 53.96^{\mathrm{b}}$ \\
\hline
\end{tabular}


Integrated Pest Management of Cotton Thrips, Thrips tabaci (Lindeman, 1889) through Selected Pesticides under Vitro Conditions

\begin{tabular}{|l|l|l|l|l|l|l|l|}
\hline \hline \multirow{2}{*}{ Acetamaprid } & 21.80 & 9.40 & 7.80 & 15.00 & 13.30 & 6.40 & $10.38 \pm 1.63$ \\
\cline { 2 - 8 } & Reduction \% & 38.31 & -47.79 & -87.70 & 44.40 & 31.98 & $-4.16 \pm 26.79^{\mathrm{ab}}$ \\
\hline \multirow{2}{*}{ Nitenpyram } & 19.13 & 2.73 & 10.40 & 12.40 & 16.50 & 7.40 & $9.89 \pm 2.32$ \\
\cline { 2 - 8 } & & & - & & & & \\
& Reduction \% & 79.58 & 124.55 & -76.82 & 21.40 & 10.37 & $-18.00 \pm 36.53^{\mathrm{ab}}$ \\
\hline Control plot & 38.00 & 26.56 & 9.20 & 13.93 & 41.70 & 16.40 & $21.56 \pm 5.78^{\mathrm{ab}}$ \\
\hline
\end{tabular}

\section{Second spray:}

The results of the second spray showed that the overall mean population of thrips was observed (15.06) in pre-treatment data collection when sprayed with Acetamaprid pesticide, the post-treatment data showed that the (34.97\%) was reduced after one day 24 hours spray. Thus, the second day on 48 hours was observed (32.77\%), on third day after 72 hours $(29.45 \%)$, on seventh day (32.27\%) and on twelfth day $(35.65 \%)$ reduced which showed the overall reduction $(33.02 \pm 1.10 \%)$ in first spray when compared with the control (un-sprayed) plot. The second pesticide Nitenpyram was observed with the overall reduction $(32.41 \pm 1.52 \%)$ followed by Acephate $(30.14 \pm 1.88 \%)$, Pyriproxyfen $(27.66 \pm 3.25 \%)$ and Diafenthiuron $(26.62 \pm 3.46 \%)$ when compared with control plot $(9.44 \pm 0.14)$ with overall mean population (Table-2), respectively. The analysis of variance showed the highly significant difference among all pesticides $(\mathrm{DF}=5,24 ; \mathrm{F}=15.5 ; \mathrm{P}=0.001)$ used to control the thrips at $(\mathrm{P}<0.05)$.

Table- 2. Overall mean and reduction \% at pre and post treatments of different pesticides against Thrips population ( $2^{\text {nd }}$ spray) under cotton field conditions

\begin{tabular}{|l|l|l|l|l|l|l|l|}
\hline \multirow{2}{*}{ Pesticides } & \multicolumn{2}{|l|}{ Post-treatment } \\
\cline { 3 - 8 } & Pre-treatment & $24 \mathrm{~h}$ & $48 \mathrm{~h}$ & $72 \mathrm{~h}$ & $\begin{array}{l}7^{\text {th }} \\
\text { day }\end{array}$ & $\begin{array}{l}12^{\text {th }} \\
\text { day }\end{array}$ & Mean and Reduction \% \pm SE \\
\hline \multirow{2}{*}{ Acephate } & 15.80 & 6.73 & 5.73 & 5.46 & 6.33 & 6.33 & $6.12 \pm 0.23$ \\
\cline { 2 - 8 } & Reduction \% & 26.30 & 32.75 & 35.92 & 29.54 & 26.19 & $30.14 \pm 1.88^{\text {a }}$ \\
\hline \multirow{2}{*}{ Diafenthiuron } & 15.86 & 7.40 & 5.80 & 5.40 & 7.23 & 6.46 & $6.46 \pm 0.39$ \\
\cline { 2 - 8 } & Reduction \% & 19.27 & 32.19 & 36.86 & 19.82 & 24.96 & $26.62 \pm 3.46^{\text {a }}$ \\
\hline \multirow{2}{*}{ Pyriproxyfen } & 16.53 & 6.40 & 6.73 & 6.93 & 7.43 & 5.60 & $6.62 \pm 0.30$ \\
\cline { 2 - 8 } & Reduction \% & 33.01 & 24.50 & 22.26 & 20.95 & 37.59 & $27.66 \pm 3.25^{\text {a }}$ \\
\hline \multirow{2}{*}{ Acetamaprid } & 15.06 & 5.66 & 5.46 & 5.73 & 5.80 & 5.26 & $5.58 \pm 0.10$ \\
\cline { 2 - 8 } & Reduction \% & 34.97 & 32.77 & 29.45 & 32.27 & 35.65 & $33.02 \pm 1.10^{\text {a }}$ \\
\hline \multirow{2}{*}{ Nitenpyram } & 15.06 & 5.40 & 5.73 & 5.66 & 5.90 & 5.46 & $5.63 \pm 0.09$ \\
\cline { 2 - 8 } & Reduction \% & 37.96 & 29.45 & 30.31 & 31.10 & 33.21 & $32.41 \pm 1.52^{\text {a }}$ \\
\hline Control plot & 17.06 & 9.86 & 9.20 & 9.20 & 9.70 & 9.26 & $9.44 \pm 0.14^{\text {b }}$ \\
\hline
\end{tabular}

\section{Third spray:}

The results of the third spray showed that the overall mean population of thrips was observed (11.46) in pre-treatment data collection when sprayed with Acetamaprid pesticide, the post-treatment data showed $(47.55 \%)$ was reduced after one day 24 hours spray. Thus, the second day on 48 hours was observed $(44.77 \%)$, on third day after 72 hours $(48.86 \%)$, on seventh day $(7.91 \%)$ and on twelfth day (3.43\%) reduced which showed the overall reduction $(30.50 \pm 10.18 \%)$ in $3^{\text {rd }}$ spray when compared with the control (un-sprayed) plot. The second pesticide Acephate was observed with the overall reduction $(27.11 \pm 4.39 \%)$ followed by Diafenthiuron $(23.14 \pm 6.95 \%)$, Nitenpyram $(22.73 \pm 6.40 \%)$ and Pyriproxyfen $(8.60 \pm 4.68 \%)$ when compared with control plot $(9.84 \pm 1.34)$ with overall mean population (Table-3). The analysis of variance showed the highly significant difference among all pesticides $(\mathrm{DF}=5,24 ; \mathrm{F}=2.09 ; \mathrm{P}=0.1019)$ used to control the thrips at $(\mathrm{P}<0.05)$, respectively.

Table- 3. Overall mean and reduction \% at pre and post treatments of different pesticides against Thrips population ( $3^{\text {rd }}$ spray) under cotton field conditions

\begin{tabular}{|l|l|l|l|l|l|l|l|}
\hline & & \multicolumn{5}{|l|}{ Post-treatment } \\
\cline { 3 - 8 } Pesticides & Pre-treatment & $24 \mathrm{~h}$ & $48 \mathrm{~h}$ & $72 \mathrm{~h}$ & $7^{\text {th }}$ day & $12^{\text {th }}$ day & Mean and Reduction $\% \pm \mathrm{SE}$ \\
\hline Acephate & 13.33 & 6.13 & 7.40 & 5.60 & 4.80 & 4.06 & $5.60 \pm 0.57$ \\
\hline
\end{tabular}


Integrated Pest Management of Cotton Thrips, Thrips tabaci (Lindeman, 1889) through Selected Pesticides under Vitro Conditions

\begin{tabular}{|l|l|l|l|l|l|l|l|}
\hline & Reduction $\%$ & 34.19 & 28.73 & 38.45 & 18.45 & 15.73 & $27.11 \pm 4.39^{\mathrm{ab}}$ \\
\hline \multirow{2}{*}{ Diafenthiuron } & 14.80 & 10.13 & 9.60 & 5.60 & 4.76 & 4.00 & $6.82 \pm 1.27$ \\
\cline { 2 - 8 } & Reduction \% & 2.05 & 16.72 & 44.56 & 27.16 & 25.23 & $23.14 \pm 6.95^{\text {abc }}$ \\
\hline \multirow{2}{*}{ Pyriproxyfen } & 10.66 & 5.60 & 7.46 & 6.95 & 4.36 & 4.00 & $5.67 \pm 0.68$ \\
\cline { 2 - 8 } & Reduction \% & 24.82 & 10.16 & 4.48 & 7.37 & -3.81 & $8.60 \pm 4.68^{\mathrm{c}}$ \\
\hline \multirow{2}{*}{ Acetamaprid } & 11.46 & 4.20 & 4.93 & 4.00 & 4.66 & 4.00 & $4.36 \pm 0.19$ \\
\cline { 2 - 8 } & Reduction \% & 47.55 & 44.77 & 48.86 & 7.91 & 3.43 & $30.50 \pm 10.18^{\mathrm{a}}$ \\
\hline \multirow{2}{*}{ Nitenpyram } & 12.26 & 6.66 & 5.46 & 5.86 & 4.86 & 4.06 & $5.38 \pm 0.44$ \\
\cline { 2 - 8 } & Reduction \% & 22.26 & 42.82 & 29.97 & 10.23 & 8.38 & $22.73 \pm 6.40^{\mathrm{abc}}$ \\
\hline Control plot & 16.60 & 11.60 & 12.93 & 11.33 & 7.33 & 6.00 & $9.84 \pm 1.34^{\mathrm{bc}}$ \\
\hline
\end{tabular}

\section{Fourth spray:}

The results of the fourth spray showed that the overall mean population of thrips was observed (8.56) in pre-treatment data collection when sprayed with Nitenpyram pesticide, the post-treatment data showed that the $(27.61 \%)$ was reduced after one day 24 hours spray. Thus, the second day on 48 hours was observed $(28.99 \%)$, on third day after 72 hours $(32.97 \%)$, on seventh day $(30.32 \%)$ and on twelfth day $(29.91 \%)$ reduced which showed the overall reduction $(29.96 \pm 0.88 \%)$ in first spray when compared with the control (un-sprayed) plot. The second pesticide Pyriproxyfen was observed with the overall reduction $(26.25 \pm 1.06 \%)$ followed by Diafenthiuron (26.86 $\pm 0.64 \%)$, Acetamaprid $(25.55 \pm 0.78 \%)$ and Acephate $(21.64 \pm 3.13 \%)$ when compared with control plot $(5.14 \pm 0.05)$ with overall mean population (Table - 4), respectively. The analysis of variance showed the highly significant difference among all pesticides $(\mathrm{DF}=5,24 ; \mathrm{F}=37.7 ; \mathrm{P}=0.001)$ used to control the thrips at $(\mathrm{P}<0.05)$.

Table- 4. Overall mean and reduction \% at pre and post treatments of different pesticides against Thrips population $\left(4^{\text {th }}\right.$ spray) under cotton field conditions

\begin{tabular}{|l|l|l|l|l|l|l|l|}
\hline \multirow{2}{*}{ Pesticides } & \multicolumn{7}{|l|}{ Post-treatment } \\
\cline { 3 - 8 } & Pre-treatment & $24 \mathrm{~h}$ & $48 \mathrm{~h}$ & $72 \mathrm{~h}$ & $7^{\text {th }}$ day & $12^{\text {th }}$ day & Mean and Reduction \% \pm SE \\
\hline \multirow{3}{*}{ Acephate } & 8.10 & 3.00 & 3.76 & 3.45 & 3.03 & 3.00 & $3.25 \pm 0.15$ \\
\cline { 2 - 8 } & Reduction \% & 27.37 & 10.71 & 18.54 & 25.63 & 25.93 & $21.64 \pm 3.13^{\mathrm{c}}$ \\
\hline \multirow{2}{*}{ Diafenthiuron } & 8.13 & 3.00 & 3.00 & 3.18 & 3.00 & 3.00 & $3.04 \pm 0.04$ \\
\cline { 2 - 8 } & Reduction \% & 27.24 & 29.02 & 25.19 & 26.64 & 26.20 & $26.86 \pm 0.64^{\mathrm{ab}}$ \\
\hline \multirow{2}{*}{ Pyriproxyfen } & 8.16 & 3.13 & 3.25 & 3.00 & 3.00 & 3.00 & $3.08 \pm 0.05$ \\
\cline { 2 - 8 } & Reduction \% & 24.78 & 23.39 & 29.69 & 26.91 & 26.47 & $26.25 \pm 1.06^{\mathrm{ab}}$ \\
\hline \multirow{2}{*}{ Acetamaprid } & 8.00 & 3.03 & 3.18 & 3.00 & 3.00 & 3.01 & $3.04 \pm 0.03$ \\
\cline { 2 - 8 } & Reduction \% & 25.73 & 23.54 & 28.28 & 25.44 & 24.75 & $25.55 \pm 0.78^{\mathrm{bc}}$ \\
\hline \multirow{2}{*}{ Nitenpyram } & 8.56 & 3.16 & 3.16 & 3.00 & 3.00 & 3.00 & $3.06 \pm 0.04$ \\
\cline { 2 - 8 } & Reduction \% & 27.61 & 28.99 & 32.97 & 30.32 & 29.91 & $29.96 \pm 0.88^{\mathrm{a}}$ \\
\hline Control plot & 10.06 & 5.13 & 5.23 & 5.26 & 5.06 & 5.03 & $5.14 \pm 0.05^{\mathrm{d}}$ \\
\hline
\end{tabular}

\section{Overall mean of all sprays:}

The results of the overall sprays showed that the overall mean population of thrips was observed (13.06) in pre-treatment data collection when sprayed with Acephate pesticide, the post-treatment data showed that the $(48.68 \%)$ was reduced after one day 24 hours spray. Thus, the second day on 48 hours was observed $(16.82 \%)$, on third day after 72 hours $(31.79 \%)$, on seventh day $(58.91 \%)$ and on twelfth day $(30.74 \%)$ reduced which showed the overall reduction $(37.39 \pm 7.38 \%)$ in overall sprays when compared with the control (un-sprayed) plot. The second pesticide Acetamaprid was observed

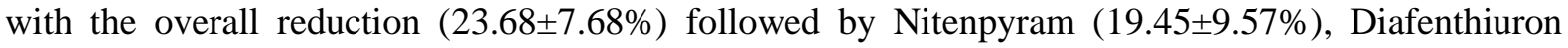
$(19.33 \pm 4.13 \%)$ and Pyriproxyfen $(1.30 \pm 16.94 \%)$ when compared with control plot $(11.50 \pm 1.35)$ with overall mean population (Table-5). The analysis of variance showed the non-significant difference 
Integrated Pest Management of Cotton Thrips, Thrips tabaci (Lindeman, 1889) through Selected Pesticides under Vitro Conditions

among all pesticides $(\mathrm{DF}=5,24 ; \mathrm{F}=1.71 ; \mathrm{P}=0.1696)$ used to control the thrips at $(\mathrm{P}<0.05)$. Among these pesticides only Acephate pesticide provided the better results up to $7^{\text {th }}$ day after application against thrips.

Table- 5. Overall mean and reduction $\%$ at pre and post treatments of different pesticides against thrips population under cotton vitro conditions during, 2015

\begin{tabular}{|l|l|l|l|l|l|l|l|}
\hline \multirow{3}{*}{ Pesticides } & \multirow{2}{*}{ Pre-treatment } & $24 \mathrm{~h}$ & $48 \mathrm{~h}$ & $72 \mathrm{~h}$ & $7^{\text {th }}$ day & $\begin{array}{l}12^{\text {th }} \\
\text { day }\end{array}$ & $\begin{array}{l}\text { Mean } \pm \text { SE } \\
\text { Reduction } \% \pm \text { SE }\end{array}$ \\
\cline { 2 - 8 } Acephate & 13.06 & 4.36 & 4.86 & 4.33 & 4.19 & 4.06 & $4.36 \pm 0.13$ \\
\cline { 2 - 8 } & Reduction \% & 48.68 & 16.82 & 31.79 & 58.91 & 30.74 & $37.39 \pm 7.38^{\mathrm{a}}$ \\
\hline \multirow{2}{*}{ Diafenthiuron } & 13.67 & 6.06 & 4.93 & 5.86 & 8.07 & 5.57 & $6.10 \pm 0.53$ \\
\cline { 2 - 8 } & Reduction \% & 31.85 & 19.39 & 11.80 & 24.38 & 9.22 & $19.33 \pm 4.13^{\text {ab }}$ \\
\hline \multirow{2}{*}{ Pyriproxyfen } & 14.14 & 7.04 & 8.01 & 10.10 & 5.88 & 5.72 & $7.35 \pm 0.80$ \\
\cline { 2 - 8 } & Reduction \% & 23.46 & -26.62 & -46.96 & 46.74 & 9.87 & $1.30 \pm 16.94^{\mathrm{b}}$ \\
\hline \multirow{2}{*}{ Acetamaprid } & 14.08 & 5.57 & 5.34 & 6.93 & 6.69 & 4.67 & $5.84 \pm 0.42$ \\
\cline { 2 - 8 } & Reduction \% & 39.19 & 15.23 & -1.26 & 39.14 & 26.11 & $23.68 \pm 7.68^{\text {ab }}$ \\
\hline \multirow{2}{*}{ Nitenpyram } & 13.75 & 4.49 & 6.19 & 6.73 & 7.57 & 4.98 & $5.99 \pm 0.56$ \\
\cline { 2 - 8 } & Reduction \% & 49.80 & -0.63 & -0.70 & 29.48 & 19.31 & $19.45 \pm 9.57^{\text {ab }}$ \\
\hline Control plot & 20.43 & 13.29 & 9.14 & 9.93 & 15.95 & 9.17 & $11.50 \pm 1.35^{\text {ab }}$ \\
\hline
\end{tabular}

Each value is a mean of 4 replications. Means in column followed by same letters are significantly different at $\mathrm{P}<0.05$.

\section{DisCUSSION}

The research study was conducted on thrips under cotton vitro conditions at district: Khairpur during, 2015 on six treatments and replicated four times based on five applications of different pesticides. The results showed that, Acephate pesticide was found more effective and Pyriproxyfen with least effective. The results are further controversial with the results of (Aslam et al., 2004), who discovered Mospilan, Confidor and Tamaron profoundly compelling against thrips whereas; the agreed with the outcomes in similarity with Stefanov and Tamaron which were very successful against the thrips as well (Wahla et al., 1997), who also found that Tamaron and Confidor were brilliant against the thrips. Further, described that the Actara surrendered suitable control to three days after spray, while Polo Diaenfenthiuron stayed slightest compelling against cotton thrips. Khaliq et al., (2014) reported that acephate was observed to be the best from spirotetramat and spinetoram, respectively, and these pesticides gave preferable control over the botanicals. Stankovac et al., (1970) assessed six pesticides for their proportional adequacy in controlling $T$. tabaci in cotton. The best control was given by monocrotophos (Azodrin) which gave entire kill of both the nymphs and adults five days after the treatment and the impact kept going up to 15 days. This was trailed by dicrotophas (Bidrin) and endosulfan (Thiodan) and others. Zolone D.T was the slightest effective.

Acephate pesticide showed the overall reduction (37.39\%) in overall sprays when compared with the control plot. The second pesticide Acetamaprid was observed with the overall reduction $(23.68 \%)$ followed by Nitenpyram (19.45\%), Diafenthiuron (19.33\%) and Pyriproxyfen (1.30\%) when compared with control plot (11.50). Another kind of pesticides with different grouped were also evaluated by (Sidhu and Dhawan, 1979) in field tests on small scale plots sprayed with eleven pesticides and analyzed two days after treatment, monocrotophos (Nuvacron) at $0.5 \mathrm{~kg}$ toxcacant (dynamic fixing) per hectare turned out to be essentially predominant (95.3\%) mortality to quinalphos and endosulfan at $0.5 \mathrm{~kg}$, which were themselves better than the rest of the pesticides utilized. Seven days after application, monocrotophos $(82.9 \%)$ mortality was still essentially better than different pesticides yet after 14 days it was slightly but not significantly inferior (70.8\% mortality) and whatever is left of the pesticides viz, phethoate, quinalphus and dimenthoate, which demonstrated comparative outcomes with no huge contrasts among them. The minimum successful pesticides were malathion and carbaryl. It was led that the monocrotophos gave the best control of T. tabaci followed by endosulfan and quinalphos. Kernal et al., (1972) tried some more current pesticides against $T$. tabaci attacking cotton in Bani-suef province of Egypt and revealed that the pesticides demonstrated 
great persistant impact up to 15 to 20 days, folimate 8496 (of unstated composition) being the best and more powerful among the four pesticides sprayed. Arranged by adequacy it was trailed by Nuvacron, Phosphamidan and Zolone D.T. (Sundra and Ramakrishan (1973) calculated the viability of spray of seven organophosphorus pesticides against thrips in India. As adjudicator by the diminishment in pest population $0.025 \%$ monocrotophos (Nuvacron) was the best treatment, trailed by $0.025 \%$ dimethioate (B1 85) Phosphamidan (Dimacron) and formothion (Anthio). Rathore et al., (1970) assessed a few pesticides for controlling T. tabaci infestation on cotton. He revealed that the pesticides giving the best outcomes upto 10 days after spraying were endrin, carbarly, monorotophos (Nuvacron) and dimethoate respectively. Every one of these pesticides has lost their power 20 days after their application.

The analysis of variance showed the significant difference among all pesticides $(\mathrm{p}<0.05)$. It is concluded that only Acephate gave the better results up to $12^{\text {th }}$ day among all pesticides therefore, it is suggested to be applied for controlling of $T$. tabaci on the cotton crop under vitro conditions. Further; the management of $T$. tabaci was also evaluated through agronomic practices in onion field by (Khaliq et al., 2016) and (Faircloth et al., 2002) also accounted that cotton seedlings were more susceptible to thrips attack and observed the effect of insecticide treatment and environmental factors on thrips population, plant growth and yield of cotton. Besides, the eco-friendly management practices were necessary to keep pest population below economic damages by assuring safe mode to beneficial reported by (Khaliq et al., 2014). Sahito et al., (2017) observed the same kind of the research studied on comparative efficacy of novel pesticides against sucking complex as jassid on cotton crop under field conditions and found significant results $(\mathrm{p}<0.05)$. Whereas; the Pyriproxyfen found less effective pesticide to the Thrips of cotton crop but this pesticide found to be lesser effective to natural enemies. It is further recommended that Acephate pesticide should be used against cotton Thrips.

\section{REFERENCES}

[1] Abbas, M.A. (2001). General agriculture. $2^{\text {nd }}$ edition. Emporium publ., Pakistan, Pp. 352.

[2] Afzal, M. (1969). The Cotton Plant in Pakistan. Pak.Central Cotton Committee, Karachi-I, Pp. 58-61.

[3] Ahmad, Z. (1999). Key paper, pest problems of cotton- A Regional Perspective. In: Proceedings of ICAC CCRI, Regional Consultation. Insecticide Res. Manag., Pp. 5-20.

[4] Ali, M.R. and M.A. Wahla. (1993). The comparative efficacy of some insecticidal spray schedules against the sucking pest insects of FH-682 cotton. Pak. Entomol., 15(1-2): 79-80.

[5] Anikwe, J.C., E.U. Asogwa, T.C.N. Ndubuaku and F.A. Okelana. (2009). Evaluation of the toxicity of Actara 25 WG for the control of the cocoa mired Sahlbergella singularis Hagl. (Hemiptera: Miridae) in Nigeria. Afr. J. Agric. Res., 8: 1528-1535.

[6] Anonymous. (2008). Economic survey of Pakistan, Ministry of Food and Agriculture, Islamabad. Pp. 1737.

[7] Aslam, M., M. Razzaq, S. Rana and M. Faheem. (2004). Comparative efficacy of different insecticides against sucking pests of cotton. J. Res. Sci., 15(1): 53-58.

[8] Carvalho, G.A., M.S. Godoy, D.S. Parreira, O. Lasmar, J.R. Souza and V.F. Moscardini. (2010). Selectivity of growth regulators and neonicotinoids for adults of Trichogramma pretiosum (Hymenoptera: Trichogrammatidae). Rev. Colomb. Entomol., 36: 195-201.

[9] Faircloth, J.C., J.R. Bradley and J.W. Duyn. (2002). Effect of insecticide treatment and environmental factors on thrips population, plant growth and yield of cotton. J. Entomol. Sci., 374: 308-316.

[10] Gupta, M.P., S. Sandeep, S.K. Shrivastava and S. Sharma. (1997). Population build-up of some sap sucking insects on cotton in Madhya Pardesh. J. Insc. Sci., 10: 153-6.

[11] Henderson, C.F. and E.W. Tilton. (1955). Tests with acaricides against the brow wheat mite. J. Econ. Entomol., 48: 157-161.

[12] Iwasa, T., N. Motoyama, J.T. Ambrose and R.M. Roe. (2004). Mechanism for the differential toxicity of neonicotinoid insecticides in the Honey bee, Apis mellifera. Crop Prot., 23: 371-378.

[13] Kernal, A.A.M., A.M. Shoeib and M.A. Azim. (1972). Effect of some newer insecticides against T. tabaci Lind. attacking cotton in Bani Suef province. Bull, Entomol. Soc. Egypt. 6 53-55. Abstracted in RAE. (A). 63 (3): 959.

[14] Khaliq, A., A.A. Khan, M. Afzal, H.M. Tahir, A.M. Raza and A.M. Khan. (2014). Field evaluation of selected botanicals and commercial synthetic insecticides against Thrips tabaci Lindeman (Thysanoptera: Thripidae) populations and predators in onion field plots. Crop Protection, 62(0): 10-15. 
[15] Khaliq, A., M. Afzal, A.A. Khan, A.M. Raza, M. Kamran, H.M. Tahir, M.A. Aqeel and M.I. Ullah. (2016). Management of Thrips tabaci (Thysanoptera: Thripidae) through agronomic practices in onion field plots. Pakistan J. Zool., 48(6): 1675-1680.

[16] Khan, M.A., I. Muhammad, A. Iftikhar and H.S. Manzoor. (2002). Economic Evaluation of Pesticide use Externalities in the Cotton Zones of Punjab, The Pak. Dev. Review. 41:4 Part II., Pp. 683-693.

[17] Khattak, M.K., M. Rashid, S.A.S. Hussain and T. Islam. (2006). Comparative effect of neem (Azadirachta indica) oil, neem seed water extract and baythroid TM against whitefly, jassids, and thrips on cotton Pak. Entomol., 28(1): 31-37.

[18] Natwick, E.T. (1999). New insecticides for control of silver leaf whitefly: An efficient evaluation. Proc. Belt-wide Cotton Conferences. National Cotton Council, Memphis TN. USA. 2: 910-920.

[19] Ozyigit, I.I., M.V. Kahraman and O. Ercan. (2007). Relation between explants age, total phenols and regeneration response in tissue cultured cotton (Gossypium hirsutum L.). Afric. J. Biotech., 6(1): 003-008.

[20] PAR (Pakistan Agriculture Research). (2016). Cotton crop in Pakistan. http://edu.par.com.pk/wiki/cotton/.

[21] Rathore, U.S., U.K. Kaushik and N.R. Sood. (1970). Control of cotton thrips: insecticide trials PANS. 16(2): 363-364.

[22] Sahito, H.A., G.H. Abro, T.S. Syed, S.A. Memon, B. Mal and S. Kaleri. (2011). Screening of pesticides against cotton mealybug, Phenacoccus solenopsis (Tinsley) and its natural enemies on cotton crop. Int. Res. J. Biochem. Bioinform., 1(9): 232-236.

[23] Sahito, H.A., Z.H. Shah, M. Ruk, M.Z. Shah and W.M. Mangrio. (2015). Toxicant efficacy of some insecticides against Whitefly, Bemisia tabaci under cotton field conditions at Khairpur-sindh. Academic J. Ento., 8(4): 193-200.

[24] Sahito, H.A., Z.H. Shah, T. Kousar, W.M. Mangrio, N.A. Mallah, F.A. Jatoi, W.A. Kubar. (2017). Comparative efficacy of novel pesticides against jassid, Amrasca biguttula biguttula (Ishida) on cotton crop under field conditions at Khairpur, Sindh - Pakistan. Singapore J. Sci. Res., Pp. 1-8.

[25] Saleem, M.A., K. Mustafa and R. Hussain. (2001). Comparative efficacy of some insecticides against some sucking insect pests of CIM443 cotton. Pak. Entomol., 23(1-2): 91-92.

[26] Shah, M.J., A. Ahmad, M. Hussain, M.M. Yousaf and B. Ahmad. (2007). Efficacy of different insecticides against sucking insect pest complex on the growth and yield of mungbean (Vigna radiata L.) Pak. Entomol., 29(2) 83-85.

[27] Shah, Z.H., H.A. Sahito, G.A. Shar, T. Kousar, W.M. Mangrio and K.A. Kanhar. (2016). Toxicity of different insecticides against mealybug, Phenacoccus solenopsis (Tinsley) under cotton field conditions. Pak. J. Entomol., 31 (1): 39-50.

[28] Sidhu, A.S. and A.K. Dhaman. (1979). Chemical control of thrips on cotton. Pesticides (Bombay), 13 (1):39. Abstracted in RAE. (A) 68 (10):5127.

[29] Stankovac, A.M., Morovic, Z. Radovanovic and Zoric. (1970). A contribution to the study of control of $T$. tabaci L. Biljoi Lekar. 15 (213): 63-67. Abstracted in RAE 60(11): 3707.

[30] Sundra, N.M., and P.K. Ramakrishan. (1973). Relative efficacy of organophosphatic insecticides against aphids and thrips on cotton. Madras Agric. J., 60(7):597. Abstracted in RAE. (A). 63 (10):4228.

[31] Uthamasamy, S. (1994). Intra and inter plant behavioural dynamics of the cotton bollworm complex. In: Functional Dynamics of Phytophagous Insects (Ed. Ananthakrishnan T. N.), Oxford and IBH Publishers, New Delhi, Pp. 115-131.

[32] Wahla, M.A., M. Tufail and M. Iqbal. (1997). The Comparative effectiveness of different doses of Confider 200 SL and Tamaron $600 \mathrm{~L}$ against the cotton Thrips (Thrips tabaci Lind.) on cotton verity FH582. Pak. Entomol., 19(2): 8-10.

[33] Wilson, L.J., and L.R. Bauer. (1993). Species composition and seasonal abundance of thrips (Thysonoptera) on cotton in the Namoi Valley. J. Australian Entomol. Soc., 32: 187-92.

[34] Yamamoto, I. (1996). Neonicotinoids- mode of action and selectivity. Agrochem. Jpn. 68: 14-15.

[35] Zhang, L., S.M. Greenberg, Y. Zhang and T. Liu. (2011). Effectiveness of thiamethoxam and imidacloprid seed treatments against Bemisia tabaci (Hemiptera: Aleyrodidae) on cotton. Pest Manag. Sci., 67: $226-232$.

Citation: Z. H. Shah et al., I. P. Sunish, "Integrated Pest Management of Cotton Thrips, Thrips tabaci (Lindeman, 1889) through Selected Pesticides under Vitro Conditions ", International Journal of Research Studies in Zoology, vol. 3, no. 4, p. 76-83, 2017. http://dx.doi.org/10.20431/2454-941X.0304011

Copyright: () 2017 Authors. This is an open-access article distributed under the terms of the Creative Commons Attribution License, which permits unrestricted use, distribution, and reproduction in any medium, provided the original author and source are credited. 